\section{The Central Role of T-Cell memory in Alzheimer's disease vaccination}

\author{
Brian Giunta, ${ }^{1,2}$ Amanda Ruscin, ${ }^{1,3,4}$ \\ Demian Obregon, ${ }^{1,3}$ Jon Salemi, ${ }^{1,3}$ \\ Alan Wolfson, ${ }^{1}$ Francisco Fernandez, ${ }^{1,3}$ \\ Jun Tan ${ }^{1,2,3}$ \\ 'Department of Psychiatry and \\ Neurosciences, Neuroimmunology \\ Laboratory, University of South Florida, \\ College of Medicine, Tampa, FL, USA; \\ ${ }^{2}$ Department of Molecular Medicine, \\ University of South Florida, College \\ of Medicine, Tampa, FL, USA; \\ ${ }^{3}$ Department of Psychiatry and \\ Neurosciences, Rashid Developmental \\ Neurobiology Laboratory, Silver Child \\ Development Center, University of South \\ Florida, College of Medicine, Tampa, FL, \\ USA; ${ }^{4}$ University of South Carolina,
} School of Medicine, Columbia, SC, USA

\section{Abstract}

Alzheimer's disease (AD) is the most common progressive neurodegenerative brain disease as well as the most common dementia among the elderly. In the future as the average lifespan continues to extend, the number of $\mathrm{AD}$ patients will continue to grow. Amyloidbeta $(\mathrm{A} \beta)$ peptides, in both soluble oligomeric, and insoluble forms, are key in the neuropathogenesis of $\mathrm{AD}$ and have thus been a therapeutic target for vaccines. Multiple $A \beta$ vaccination strategies in animal models of $A D$ have demonstrated a marked reduction in both amyloid burden and neurocognitive deficits. Due to the success of these studies, initial human clinical trials of an active $A \beta$ vaccine were conducted. These were discontinued due to the development of meningoencephalitis in approximately $6 \%$ of the vaccinated $\mathrm{AD}$ patients. Studies examining the brains of $A \beta$ vaccinated patients developing meningoencephalitis implicate A $\beta$-reactive T-cell subsets as major components of this deleterious response to active $A \beta$ vaccination. To subvert possible meningoencephalitis resulting from $A \beta$ vaccination a second generation of vaccines has been more recently developed. These however have met with little success in humans. To build on these findings, an understanding of the role of T-cells in vaccination against $A \beta$ is presented in this review. Various methods of $A \beta$ immunotherapy are reviewed including studies in both animal models and humans. Recent works suggest that $A \beta$ derived peptides delivered intranasally or transcutaneously results in effective clearance of
$\mathrm{A} \beta$ plaques and improvement of cognitive function in animal models of AD. Moreover, undesired T-cell reactivity appeared to be considerably reduced compared with other active immunization strategies. In spite of the past clinical studies, these findings imply that $A \beta$ vaccination may be both efficacious and safe depending route of delivery, adjuvant choice, and $\mathrm{A} \beta$ epitope administered.

\section{Introduction}

First characterized in 1907, Alzheimer's Disease (AD), is the most common cause of dementia and affects 5 million people in the United States. The prevalence of the disease increases exponentially with advancing age. ${ }^{1}$ About $1 \%$ of persons aged 65 years have $\mathrm{AD}$, and the percentage increases to almost $50 \%$ in persons greater than 85 years of age. In the United States, this phenomenon is in part secondary to life expectancy increasing by some $50 \%$, from 50 years of age in 1900 , to 75 years of age in 2000. This has resulted in a modern threefold increase in the percentage of persons over 65 . The problem is worldwide however. Thus a prophylactic or curative treatment for AD would have enormous benefits.

The cerebral amyloid beta (A $\beta$ ) protein deposits in $\mathrm{AD}$ are primarily found postmortem in two brain regions: scattered in the extracellular neocortex and limbic system and in the walls of cerebral blood vessels. ${ }^{2}$ These deposits consist of amyloid fibrils in a $\beta$-pleated sheet conformation made up of mixed polymers of the 40 and 42 amino acid $\mathrm{A} \beta$ peptides. ${ }^{1,3}$ The DNA sequence coding for $A \beta$ is a small portion of a larger gene encoding a transmembrane amyloid precursor protein (APP). APP undergoes proteolysis by two enzyme complexes, beta $(\beta)$ and gamma $(\gamma)$ secretases, to generate the $A \beta$ peptide. ${ }^{4-6}$ Additionally, increasing evidence supports soluble oligomeric forms of $\mathrm{A} \beta$, particularly dimers as an equally, if not more, neurotoxic species. ${ }^{7,8}$

\section{The biology of T-cell memory in vaccination}

An understanding of immunological memory and its relationship to an effective vaccine against $\mathrm{AD}$ is a key issue in medical neuroimmunology. Primary immunization or "priming" causes antigen-specific T-cells to proliferate, yielding large pools of effector T-cells which move into peripheral tissues to combat pathogens or proteins. A portion of these "primed" T-cells develop into memory cells, which provide immediate protection and the ability to mount a faster and effective secondary immune response. ${ }^{9,10}$
Correspondence: Brian Giunta, Department of Psychiatry and Neurosciences, University of South Florida College of Medicine, 3515 E. Fletcher Ave., MDC14, Tampa, FL 33613, USA. E-mail: bgiunta@health.usf.edu

Key words: Alzheimer, dementia, vaccine, T-cells, microglia.

Acknowledgments: this work was supported by: NIH/NIMH (1 K08 MH082642-01A1, B.G.), NIH/NIA (AG04418/Project-2, J.T.; R01AG032432, J.T.), VA grant (BX000129, J.T.), and NIH/NINDS (R01NS048335, J.T.).

Received for publication: 26 0ctober 2010.

Revision received: 26 October 2010.

Accepted for publication: 6 October 2010.

This work is licensed under a Creative Commons Attribution 3.0 License (by-nc 3.0).

(C) Copyright B. Giunta et al., 2010

Licensee PAGEPress, Italy

Ageing Research 2010; 2:e5

doi:10.4081/ar.2010.e5

Memory T-cells comprise at least two subsets, each with distinctive migratory and effector capacities. ${ }^{11-13}$ Cells of the first subset are somewhat similar to the effector cells generated in the primary response in that they lack lymph node-homing receptors (L-selectin and chemokine receptor type 7 [CCR7]) and express receptors for migration into inflamed tissue. Upon re-encounter with antigen, these effector memory T-cells (TEM) quickly release interferon-gamma (IFN- $\gamma$ ), Interleukin (IL)-4, or perforin. T-cells in the second subset express L-selectin and CCR7 as do naive Tcells) and do not possess immediate effector function. These central memory T-cells (TCM) have a low activation threshold and, upon restimulation in secondary lymphoid organs, proliferate and differentiate into effectors..$^{12-15}$

Many of these T-cells are positive for CD8 (cluster of differentiation 8), a transmembrane glycoprotein that serves as a co-receptor for the T-cell receptor (TCR). Importantly, the distribution of peripheral T-cell subsets in young and healthy elderly individuals is distinctly different, marked by decreased naïve cells and increased clonal expansions of memory $\mathrm{CD}^{+}$major histocompatibility complex (MHC) class I-restricted T-cells. ${ }^{16,17}$

As with the CD8 T-cells the differentiation process for CD 4 (cluster of differtiation 4) Tcells is controlled by both TCR and cytokine stimulation. ${ }^{18} \mathrm{CD}^{+}$T-cells have traditionally been divided into two subsets based on their cytokine expressing repertoire. That is, Thelper 1 (Th1) cells are pro-inflammatory while, T-helper 2 (Th2) cells are considered anti-inflammatory. ${ }^{19}$ In regard to Th1 cells, prolonged TCR stimulation in the presence of IL 
(interleukin) -12 or IL-4 promotes terminal differentiation to effector Th1 or Th2 cells respectively. Notably, AD is marked by primarily Th1 response in the brain. ${ }^{20,21}$ A short TCR stimulation period and TGF- $\beta$ preserve the cells in a central memory-like stage. ${ }^{14,18,22}$

Thus in both $\mathrm{CD}^{+}$and $\mathrm{CD} 4^{+}$T-cells, terminal differentiation is not a necessary consequence of T-cell activation. The generation of resting intermediates that endure as central memory cells provides the immune system with a reserve of highly sensitive cells that can be quickly recruited in secondary immune activation responses; thus generating large pools of potent CD4 or CD8 effector cells. ${ }^{23,24}$ This is important since peripheral T-cell activation likely leads to CNS immune activation when the blood-brain barrier (BBB) permeability may be compromised, as in $\mathrm{AD} .^{25}$

\section{A $\beta$-reactive T-cells}

Recently Monsonego and colleagues, demonstrated T-cell reactivity to the more immunogenic peptide $A \beta_{1-42}{ }^{26}$ instead of $A \beta 1$ $40 .^{7}$ On the other hand, T-cells were infrequently stimulated by the $\mathrm{N}$-terminal region 1 28 residues. An analysis of A $\beta$ T-cell epitopes and their restriction to HLA (human leukocyte antigen)-DR class II showed A $\beta$ is processed and presented through MHC by APCs and that $\mathrm{A} \beta$-specific T-cell proliferation is mediated through MHC-TCR interactions. Thus, $A \beta$ is able to confer an adaptive immune response in the periphery. ${ }^{27}$

There have been at least two other previous studies in humans measuring $\mathrm{A} \beta_{1-40}$ reactive Tcells in the peripheral circulation. The first ${ }^{26}$ reported $A \beta$-induced $\mathrm{T}$-cell proliferation in young and elderly controls but that these Tcells were not present in $\mathrm{AD}$ patients. It was hypothesized A $\beta$-reactive peripheral T-cells were anergized in $\mathrm{AD}$ patients. On the other hand, others found activation and expansion of A $\beta$-reactive T-cells in the elderly and patients with $\mathrm{AD}$ indicates $\mathrm{A} \beta$ is captured by local APCs in the brain, and that these APCs migrate to secondary lymph nodes; inducing T-cell activation. ${ }^{7}$ Although A $\beta$ deposition occurs in elderly humans that do not have overt signs of $\mathrm{AD}$, there appears to be increased T-cell reactivity to $\mathrm{A} \beta$ in patients with $\mathrm{AD}$, since in contrast to elderly subjects, all patients in Monsonego and colleagues' study with $\mathrm{AD}$ had some $\mathrm{A} \beta$ reactivity. ${ }^{7}$ Such reactivity could reflect an endogenous reaction to $A \beta$ deposition which we observed as local innate immune response in AD brain post-mortem. ${ }^{27}$

Thus it could be said that some $A \beta$ reactive T-cell pools in the CNS (i.e. those present in $\mathrm{AD}$ patients ${ }^{26,27}$ enhance the cognitive decline process whereas as those present in the periphery in individuals of any age $^{25}$ seem neuroprotective.

\section{Animal $A \beta$ immunization}

Evidence directly linking $A \beta$ to symptoms of $\mathrm{AD}$ first came from transfecting a mutant human APP (amyloid precursor protein) gene from a patient with hereditary $\mathrm{AD}$ into the murine genome (APP-transgenic mouse); yielding cerebral $\mathrm{A} \beta$ plaques and cognitive deficits. ${ }^{4}$ Several transgenic mouse models of $\mathrm{AD}$ that express human, mutant APP genes, alone or in combination with human, mutated presenilin and tau genes now exist. ${ }^{28}$

Regarding vaccination strategies, Schenk and colleagues ${ }^{29}$ first showed vaccination with $\mathrm{A} \beta_{1-42}$ and Freund's adjuvant ameliorated $\beta$ amyloid generation in brains of young transgenic mice and decreased $\beta$-amyloid in aged mice with pre-existing $\mathrm{AD}$ pathology including quantity and density of $A \beta$ plaques in the brain, with related improvements in neuritic dystrophy and gliosis. ${ }^{29}$ Later, active vaccinations in transgenic mice, nonhuman primates, and other species further confirmed these results. ${ }^{30 \cdot 34}$

Passive transfer of anti- $A \beta$ antibodies is also able to efficiently reduce $\beta$-amyloid pathology in animal. ${ }^{3441}$ The vaccine-mediated clearance of $\beta$-amyloid pathology in animal models is reflected by the recovery of neuronal and cytoskeletal morphology, ${ }^{42-44}$ by improvement of neurotransmission,,$^{31,44,45}$ and $^{45,46}$ and most importantly by improved cognitive functions. $^{47-49}$

From animal studies, two theories (not mutually exclusive) of the mechanisms by which $\mathrm{A} \beta$ antibodies work have been developed. First, Fc-mediated uptake and clearance of $A \beta$ antibody complexes by microglia has been demonstrated.$^{50}$ Second, evidence of a net efflux of $A \beta$ peptide out of the brain and into the serum and the cerebrospinal fluid (CSF), as a result of its binding and mobilization by $\mathrm{A} \beta$ antibodies, has been obtained..$^{51,52}$

In addition to these paradigms, because primarily local innate inflammation occurs in $\mathrm{AD}$ brain, an immune balance by induction of specific adaptive, Th2, immune responses has been demonstrated to be beneficial in animal models of AD.

Some examples of this can be seen in the literature whether investigators are exploring immunization with forms of $A \beta$ peptide, or by immunization with a gene encoding $A \beta$. HongDuck and colleagues demonstrated an adenovirus encoding 11 tandem repeats of $A \beta_{1-6}$ fused to the receptor-binding domain (Ia) of Pseudomonas exotoxin A (PEDI) or AdPEDI$\left(\mathrm{A} \beta_{1-6}\right)_{11}$ can induce anti-inflammatory Th2 immune response in mice. They then went on to explore whether a DNA prime-adenovirus boost regimen could elicit a more robust Th2 response using AdPEDI-(A $\left.\beta_{1-6}\right)_{11}$ and a DNA plasmid encoding the same antigen. All mice administered DNA prime-adenovirus boost regimen were positive for anti-A $\beta$ antibody, while, out of seven mice immunized with only AdPEDI- $\left(A \beta_{1-6}\right)_{11}$, four mice developed anti-A $\beta$ antibody. The mean anti-A $\beta$ titer induced by the DNA prime-adenovirus boost regimen was some7-fold greater versus the AdPEDI- $\left(\mathrm{A} \beta_{1-6}\right)_{11}$ alone. ${ }^{53}$

Further, genetic immunization with the $A \beta_{1-42}$ gene in $\mathrm{AD}$ transgenic mice effectively elicited a humoral immune response without a significant T-cell-mediated immune response to the $A \beta$ peptide..$^{54}$

Additionally, papillomavirus-like particles (VLP) have also been employed which display $\mathrm{A} \beta_{1-9}$ protein repetitively on the capsid surface. This peptide contains a functional B cell epitope, but lacks T-cell epitopes. Rabbit and mouse vaccinations were well tolerated and induced high-titer antibody against $A \beta$, that effectively inhibited assembly of $A \beta_{1-42}$ peptides into neurotoxic fibrils in vitro. ${ }^{55}$ In PSAPP mice trends for reduced brain $A \beta$ deposits, and increased $A \beta$ in plasma, suggested efflux from the brain to periphery as well..$^{51,52}$ These results are important because the Th2 response is salutary in the CNS in AD.

Also to induce Th2-polarized immune responses, some groups used other B cell epitopes of $A \beta^{53}$ such as $A \beta_{1-15}$, Th2-type adjuvants such as IL-4, ${ }^{17,56,58}$ Alum, ${ }^{56,57}$ mannan,${ }^{56}$ mono phosphoryl lipid A, cholera toxin B subunit, $E$. coli enterotoxin, ${ }^{59}$ and transcutaneous ${ }^{60}$ or mucosal vaccination. ${ }^{33}$ Thus overall it seems immunization modalities conferring predominantly Th2 type immune responses are safer for $\mathrm{AD}$ prevention and treatment. ${ }^{7,52,61-63}$

\section{Development of anti- $A \beta$ vaccina- tion in humans}

An obstacle to introducing a vaccine mediated immune response in humans is that $\mathrm{AD}$ patients already experience a chronic inflammatory process surrounding neuritic plaques. In $\mathrm{AD}$ an innate immune response is triggered by local production of $A \beta$ protein. ${ }^{27}$ Innate immune involvement is evident from the complement proteins of the by activation of microglia, resulting in the release of proinflammatory cytokines and chemokines (for further review see, ${ }^{21}$ ). Additionally, $A \beta$ fibrils can be modified by endogenous sugars to form "advanced glycation endproducts" (AGEs), which in turn activate pro-inflammatory signal transduction pathways in which the receptor for AGEs (RAGE), and oxygen free radicals (as second messengers) are produced in excess. $\mathrm{A} \beta$ and AGEs activate transcription factors leading to upregulation of neurotoxic cytokines including IL-1, IL-6 and TNF- $\alpha{ }^{64-67}$ The inflammatory pathology (microgliosis, astrocytosis, complement activation, increased cytokine expression and acute phase protein response) is thought to be a secondary response to early accumulation of brain $A \beta$.

As in animal models, it is possible that an 
adaptive immune response accompanied by Th2 type cytokine predominance may indicates a "successful" response to vaccination. This would be observed as a lack of meningoencephalitis and antibodies bound to neuritic plaques facilitating antibody mediated clearance of $A \beta$ from the brain. In this case, the innate $A \beta$ brain inflammation should halt after the plaque burden has decreased, and this should be accompanied by a stabilization, or even recovery of cognitive function. Indeed, accumulation of $A \beta$ in the brain has been suggested to be caused by an impaired capacity to clear the protein in $\mathrm{AD}$ patients. ${ }^{2}$

Initial phase I and phase II clinical (Elan/Wyeth AN1792) trials were conducted with aggregated $A \beta_{1-42}$ and the QS-21; a Th1 response-activating adjuvant. ${ }^{68,69}$ In the late stages of the phase I trial polysorbate 80 , an emulsifying agent, was added to the active vaccine. It was at this time that immune responses shifted from a predominantly Th2-polarized response to a pro-inflammatory Th1 response ${ }^{69}$ marked by meningoencephalitis and vascular T-lymphocyte infiltrations. ${ }^{70}$ The mechanism of this self- reaction is unknown. However the appearance of the inflammation prior to detection of $A \beta$ antibodies in some of the patients suggests a T-cell-mediated immune reaction to $A \beta$, which caused bystander damage to the brain, was at work. In the later phase II trial in 2002 by Elan and Wyeth, 18 further patients ( $6 \%$ of the patients treated with the active vaccine) developed subacute aseptic meningoencephalitis after having received mostly two doses, and in some cases one or three of the initially planned six doses of the active vaccine. ${ }^{71}$ Two participants suffered ischemic strokes as well. The active vaccination also led to a humoral immune response in some of the vaccinated patients with significantly increased IgG and IgM titers. ${ }^{68,72,73}$ These antibody titers were unrelated to the occurrence or severity of meningoencephalitis. ${ }^{71}$ Further, one individual with severe meningoencephalitis had no detectable antibody titers suggesting the humoral response was not required to cause meningoencephalitis.

Long-term follow-up of the Elan phase I/II study cohort of actively vaccinated patients revealed increased titers of antibodies reacting with brain $\beta$-amyloid plaques. ${ }^{74}$ Indeed 19 patients with serum $\beta$-amyloid plaque-reactive antibodies showed slower cognitive decline over a 1-year period than did nine patients who did not develop these antibodies. Although the cohort size was quite small, this finding suggests anti- $\beta$-amyloid antibodies as protective. ${ }^{75}$ However, when all participants were analyzed, no overall significant differences on cognitive performance were found between the placebo and treatment groups. ${ }^{72,76}$ This may have been related to the relatively small decline in ADAScog (Alzheimer's Disease Assessment Scale- cognitive subscale) scores in the placebo group. ${ }^{72,77}$

Autopsy tissues from patients who died from unrelated causes showed patchy patterns of $\beta$ amyloid plaque clearance associated with increased antibody titers, with some regions almost totally free of $\beta$-amyloid plaques ${ }^{70,71,78,79}$ In several cases, $\beta$-amyloid plaque reductions were associated with increased brain tissue concentrations of water and detergent-soluble forms of $A \beta{ }^{80}$ suggesting some biological plaque-clearing activity of antibodies occurred as a result of vaccination. No $\beta$-amyloid clearance was observed in a single case without detectable antibody titers. ${ }^{80}$ These results point to biologically important effects of $A \beta$ antibodies on $\beta$-amyloid plaque pathology in $\mathrm{AD}$.

However with increasing evidence supporting oligomeric $A \beta$ as the more neurotoxic species,${ }^{7,8}$ there may be a low therapeutic value for clearing of already well established parenchymal plaques for the improvement of cognitive decline in human $\mathrm{AD}$ patients. Prevention or efficient clearing of toxic oligomeric $A \beta$ may be more effective. Because of $A \beta$ reactivity in $\mathrm{AD}$ patients, ${ }^{7}$ the use of a full-length $\mathrm{A} \beta$ peptide, and the use of a Th1 adjuvant (QS21), it is comprehensible how the Elan vaccination may have caused aseptic meningoencephalitis. Further, it is important to point out that another potential problem with the Elan trial is that the vaccine consisted solely of $A \beta$. Activation of $B$ cells requires T-cell help and because the vaccine consisted solely of $A \beta$, the T-cell help required for the induction of strong IgG antibody responses was, by necessity, directed against $\mathrm{A} \beta$ itself.

To reconcile this side effect of the human study with all the previous animal trials not demonstrating it, it is necessary to understand that increased T-cell $A \beta$ reactivity has not been demonstrated in APP transgenic mice. This may be secondary to their high levels of peripheral $A \beta$ and resulting induction of T-cell tolerance. ${ }^{7}$ It has also been suggested the encephalitis may also result from antigen spreading and expansion of T-cell clones specific to myelin antigens such as myelin basic protein.

These combined data from the pre-clinical experiments and the initial clinical active vaccination trials led to the next generation of $\mathrm{AD}$ vaccines, presumably safer active vaccines with less strong Th1-cell activating formulations and with $\mathrm{C}$-terminally truncated $\mathrm{A} \beta$ fragments (since the $\mathrm{A} \beta \mathrm{C}$-terminus contains $\mathrm{T}$ cell activating epitopes). One advantage of the second generation conjugate vaccines being tested is that $\mathrm{T}$ helper epitopes are either absent or provided by a conjugate, not $\mathrm{A} \beta{ }^{81}$ Several active vaccination approaches are currently tested in clinical trials (www.clinicaltrials.gov) at the time of this review including the Merck V950 trial, the Novartis/Cytos CAD-
106 trial using a VLP-linked N-terminal $A \beta$ peptide fragment, as well as the Affiris Affitope $\mathrm{AD} 01$ and $\mathrm{AD} 02$ active vaccination trials with $\mathrm{A} \beta$ peptide mimetics. The Elan/Wyeth ACC-001 phase II active vaccination trial with an $\mathrm{N}$-terminal $A \beta$ peptide fragment conjugated to a carrier protein was suspended due to transient skin lesions in one patient in the study.

Efforts are underway to determine the basis for the adverse inflammatory reaction seen in the first generation of $\mathrm{AD}$ vaccines, and to model it in animals. In this regard, we developed a transcutaneous (t.c.) active $A \beta$ vaccination in a transgenic mouse model of AD. PSAPP mice showed high $A \beta$ antibody titers. Most importantly, t.c. immunization with $A \beta_{1-42}$ plus a cholera toxin (CT) adjuvant resulted in significant decreases in cerebral $\mathrm{A} \beta_{1-40,42}$ levels coincident with increased circulating levels of $\mathrm{A} \beta_{1-40,42}$ suggesting brain-to-blood efflux of the peptide. Importantly there was no brain T-cell infiltration or cerebral microhemorrhage. ${ }^{60}$ Other groups have also found no abnormal effects in APP transgenic mouse models to which $\mathrm{A} \beta$ antibodies have been administered, and such mice have shown robust behavioral improvements and clearing of brain $A \beta$ deposits. $^{34,82}$ It is important to consider however, that the antibody response in mice is elicited against the human form of $A \beta$, which has an amino acid sequence that differs from the mouse form. Thus, production of high titer antibodies against the non-functional human $A \beta$ are observed ${ }^{60,83}$ while limiting the humoral and cell-mediated response against the endogenous mouse $A \beta$ sequence. Therefore, the autoimmune response in mice is less likely to confer collateral damage by targeting functionally important APP and soluble A $\beta{ }^{84}$ It should also be noted that a number of other groups have shown that passive vaccination increases the degree of cerebral amyloid angiopathy and associated microbleeds. ${ }^{38,41,85,86}$ Salloway and colleagues (2009) explored vaccination of Bapineuzumab, a humanized anti- $A \beta$ monoclonal antibody, as a potential passive vaccine strategy in a multiple ascending dose, safety, and efficacy study in mild to moderate AD $(\mathrm{N}=234)$. Patients received 6 antibody infusions, 13 weeks apart, with final assessments (via ADAS-Cog) at week 78. Primary efficacy outcomes in this phase 2 trial were not significant and six vasogenic edema patients experienced transient symptoms. ${ }^{87}$

Th2 memory effector cells are a requirement for antibody production but in the elderly, the predominant T-cell population is Th1 cells, which generate the proinflammatory cytokines when stimulated by $A \beta$ vaccination. We and others hypothesize this predisposes individuals to develop $\mathrm{AD}$ as well as other age related diseases. ${ }^{88.91}$ Indeed in the elderly the $A \beta$-specific T-cell clones are composed largely of CD8positive cytotoxic T-cells, which can lyse cells 
presenting the $A \beta$ sequence. ${ }^{92}$ Thus any increase in T-cell mediated neuroinflammation from vaccination runs the risk of accelerating neuronal loss in $\mathrm{AD}$ patients who are already have a low threshold for CNS damage due to the high levels of oxidative stress and inflammation. $^{93,94}$ A further complication relates to a difficulty in being able to limit the inflammatory response to the insoluble $A \beta$ in plaques while sparing soluble $A \beta$ monomers, the parent protein [amyloid precursor protein (APP)] and neurotrophic APP fragments ${ }^{84}$ such as s-APP ${ }^{95}$

In further relation to the possible toxicity of vaccinations, the majority of the $A \beta$ epitope is localized to the extracellular portion of APP. As such, antibodies to $A \beta$ might recognize native cell surface APP, leading to complement activation, subsequent opsonisation, and brain cell injury or death. Importantly, self-reactive Tcells of low-to-moderate binding affinity are not all automatically deleted during negative selection in the thymus. ${ }^{96,97}$ Indeed a portion of autoreactive T-cells undergo positive selection and maintain the normal immune repertoire. ${ }^{98}$ Moreover, although the CNS is known as immunologically privileged, activated T-cells can routinely penetrate the BBB. ${ }^{99-101}$

Conversely, Th2 cytokine promoting or producing cells may have salutary regulatory properties. A $\beta$ administered intranasally to APP transgenic mice induced anti-A $\beta$ antibodies and partial clearance of $A \beta$ plaques. This was in conjunction with infiltration into the CNS of small numbers of mononuclear cells expressing anti-inflammatory Th2 cytokines IL-4, IL10 , and TGF- $\beta .^{33}$ Interestingly, nearly all human A $\beta$-reactive T-cell lines showed a Th2 phenotype. Thus it is possible mucosal immunization could boost this lineage, enhancing clearance of $\mathrm{A} \beta$ by both stimulating $\mathrm{A} \beta$ antibody production and modulating microglial activation at sites of $A \beta$ plaques, with a minimal risk of harmful T-cell responses in the CNS. Further, overexpression of Th- 2 cytokine TGF- $\beta$ in the CNS of APP transgenic mice resulted in a significant reduction of $A \beta$ plaques via promotion of microglial clearance of the peptide. ${ }^{102}$

Taken together, both human and animal findings imply that $A \beta$ vaccination may be both efficacious and safe provided the route of delivery, adjuvant choice, and $\mathrm{A} \beta$ epitope choice are properly combined to avoid deleterious T-cell activation in the CNS.

\section{References}

1. Glenner GG. The pathobiology of Alzheimer's disease. Annu Rev Med 1989; 40:45-51.

2. Weksler ME, Pawelec G, Franceschi C. Immune therapy for age-related diseases.
Trends Immunol 2009;30:344-50.

3. Glenner GG, Murphy MA. Amyloidosis of the nervous system. J Neurol Sci 1989;94: 1-28.

4. Games D, Adams D, Alessandrini R, et al. Alzheimer-type neuropathology in transgenic mice overexpressing V717F betaamyloid precursor protein. Nature 1995; 373:523-7.

5. Rezai-Zadeh K, Douglas Shytle R, Bai Y, et al. Flavonoid-mediated presenilin-1 phosphorylation reduces Alzheimer's disease beta-amyloid production. J Cell Mol Med 2009;13:574-88.

6. Rezai-Zadeh K, Shytle D, Sun N, et al. Green tea epigallocatechin-3-gallate (EGCG) modulates amyloid precursor protein cleavage and reduces cerebral amyloidosis in Alzheimer transgenic mice. J Neurosci 2005;25:8807-14.

7. Monsonego A, Zota V, Karni A, et al. Increased $\mathrm{T}$ cell reactivity to amyloid beta protein in older humans and patients with Alzheimer disease. J Clin Invest 2003;112: 415-22.

8. Shankar GM, Li S, Mehta TH, et al. Amyloid-beta protein dimers isolated directly from Alzheimer's brains impair synaptic plasticity and memory. Nat Med 2008;14: 837-42.

9. Ahmed R, Gray D. Immunological memory and protective immunity: understanding their relation. Science 1996;272:54-60.

10. Zinkernagel RM. On immunological memory. Philos Trans R Soc Lond B Biol Sci 2000;355:369-71.

11. Sallusto F, Lenig D, Förster R, et al. Two subsets of memory T lymphocytes with distinct homing potentials and effector functions. Nature 1999;401:708-12.

12. Reinhardt RL, Khoruts A, Merica R, et al. Visualizing the generation of memory CD4 $\mathrm{T}$ cells in the whole body. Nature 2001; 410:101-5.

13. Masopust D, Vezys V, Marzo AL, Lefrançois L. Preferential localization of effector memory cells in nonlymphoid tissue. Science 2001;291:2413-7.

14. Iezzi G, Scheidegger D, Lanzavecchia A. Migration and function of antigen-primed nonpolarized T lymphocytes in vivo. J Exp Med 2001;193:987-93.

15. Denucci CC, Mitchell JS, Shimizu Y. Integrin function in T-cell homing to lymphoid and nonlymphoid sites: getting there and staying there. Crit Rev Immunol 2009;29:87-109.

16. Larbi A, Pawelec G, Witkowski JM, et al. Dramatic shifts in circulating CD4 but not CD8 T cell subsets in mild Alzheimer's disease. J Alzheimers Dis 2009;17:91-103.

17. Larbi A, Fulop T, Pawelec G, Immune receptor signaling, aging and autoimmunity. Adv Exp Med Biol 2008;640:312-24.
18. Iezzi G, Scotet E, Scheidegger D, Lanza vecchia $A$. The interplay between the duration of TCR and cytokine signaling determines T cell polarization. Eur J Immunol 1999;29:4092-101.

19. Elenkov IJ, Chrousos GP. Stress Hormones, Th1/Th2 patterns, Pro/Anti-inflammatory Cytokines and Susceptibility to Disease. Trends Endocrinol Metab 1999;10:359-368.

20. Reale M, Iarlori C, Feliciani C, Gambi D. Peripheral chemokine receptors, their ligands, cytokines and Alzheimer's disease. J Alzheimers Dis 2008 14:147-59.

21. Giunta B, et al. Inflammaging as a prodrome to Alzheimer's disease. J Neuroinflammation 2008;5:51.

22. Langenkamp A, Messi M, Lanzavecchia A, Sallusto F. Kinetics of dendritic cell activation: impact on priming of TH1, TH2 and nonpolarized T cells. Nat Immunol 2000;1: 311-6.

23. Sallusto F, Kremmer E, Palermo B, et al. Switch in chemokine receptor expression upon TCR stimulation reveals novel homing potential for recently activated T cells. Eur J Immunol 1999;29:2037-45.

24. Sallusto F. The role of chemokines and chemokine receptors in $\mathrm{T}$ cell priming and Th1/Th2-mediated responses. Haematologica 1999;84:28-31.

25. Zipser BD, Johanson CE, Gonzalez L, et al. Microvascular injury and blood-brain barrier leakage in Alzheimer's disease. Neurobiol Aging 2007;28:977-86.

26. Trieb K, Ransmayr G, Sgonc R, et al. APP peptides stimulate lymphocyte proliferation in normals, but not in patients with Alzheimer's disease. Neurobiol Aging 1996;17:541-7.

27. Weiner HL, Selkoe DJ. Inflammation and therapeutic vaccination in CNS diseases. Nature 2002;420:879-84.

28. Morrissette DA, Parachikova A, Green KN, LaFerla FM. Relevance of transgenic mouse models to human Alzheimer disease. J Biol Chem 2009;284:6033-7.

29. Schenk D, Barbour R, Dunn W, et al. Immunization with amyloid-beta attenuates Alzheimer-disease-like pathology in the PDAPP mouse. Nature 1999;400:173-7.

30. Knobloch M, Farinelli M, Konietzko U, et al. Abeta oligomer-mediated long-term potentiation impairment involves protein phosphatase 1-dependent mechanisms. J Neurosci 2007;27:7648-53.

31. Klyubin I, Walsh DM, Lemere CA, et al. Amyloid beta protein immunotherapy neutralizes Abeta oligomers that disrupt synaptic plasticity in vivo. Nat Med 2005; 11:556-61.

32. Janus C, Pearson J, McLaurin J, et al. A beta peptide immunization reduces behavioural impairment and plaques in a model of Alzheimer's disease. Nature 2000;408: 
979-82.

33. Weiner HL, Lemere CA, Maron R, et al. Nasal administration of amyloid-beta peptide decreases cerebral amyloid burden in a mouse model of Alzheimer's disease. Ann Neurol 2000;48:567-79.

34. Bard F, Cannon C, Barbour R, et al. Peripherally administered antibodies against amyloid beta-peptide enter the central nervous system and reduce pathology in a mouse model of Alzheimer disease. Nat Med 2000;6:916-9.

35. Bacskai BJ, Kajdasz ST, Christie RH, et al. Imaging of amyloid-beta deposits in brains of living mice permits direct observation of clearance of plaques with immunotherapy. Nat Med 2001;7:369-72.

36. DeMattos RB, Bales KR, Cummins DJ, et al. Peripheral anti-A beta antibody alters CNS and plasma A beta clearance and decreases brain A beta burden in a mouse model of Alzheimer's disease. Proc Natl Acad Sci U S A 2001;98:8850-5.

37. Das P, Howard V, Loosbrock N, et al. Amyloid-beta immunization effectively reduces amyloid deposition in FcRgamma/- knock-out mice. J Neurosci 2003;23: 8532-8.

38. Wilcock DM, Rojiani A, Rosenthal A, et al. Passive amyloid immunotherapy clears amyloid and transiently activates microglia in a transgenic mouse model of amyloid deposition. J Neurosci 2004;24: 6144-51.

39. Wilcock DM, Rojiani A, Rosenthal A, et al. Passive immunotherapy against Abeta in aged APP-transgenic mice reverses cognitive deficits and depletes parenchymal amyloid deposits in spite of increased vascular amyloid and microhemorrhage. J Neuroinflammation 2004;1:24.

40. Boyett KW, DiCarlo G, Jantzen PT, et al. Increased fibrillar beta-amyloid in response to human clq injections into hippocampus and cortex of APP+PS1 transgenic mice. Neurochem Res 2003;28:8393.

41. Wilcock DM, Jantzen PT, Li Q, et al. Amyloid-beta vaccination, but not nitrononsteroidal anti-inflammatory drug treatment, increases vascular amyloid and microhemorrhage while both reduce parenchymal amyloid. Neuroscience 2007;144:950-60.

42. Lombardo JA, Stern EA, McLellan ME, et al. Amyloid-beta antibody treatment leads to rapid normalization of plaque-induced neuritic alterations. J Neurosci 2003;23: 10879-83.

43. Oddo S, Billings L, Kesslak JP, et al. Abeta immunotherapy leads to clearance of early, but not late, hyperphosphorylated tau aggregates via the proteasome. Neuron 2004;43:321-32.
44. Klyubin I, Betts V, Welzel AT, et al. Amyloid beta protein dimer-containing human CSF disrupts synaptic plasticity: prevention by systemic passive immunization. J Neurosci 2008;28:4231-7.

45. Bales KR, Tzavara ET, Wu S, et al. Cholinergic dysfunction in a mouse model of Alzheimer disease is reversed by an anti-A beta antibody. J Clin Invest, 2006. 116:825-32.

46. Mohajeri MH, Saini K, Schultz JG, et al. Passive immunization against beta-amyloid peptide protects central nervous system (CNS) neurons from increased vulnerability associated with an Alzheimer's disease-causing mutation. J Biol Chem 2002;277:33012-7.

47. Morgan D, Diamond DM, Gottschall PE, et al. A beta peptide vaccination prevents memory loss in an animal model of Alzheimer's disease. Nature 2000;408:982-5.

48. Sigurdsson EM, Knudsen E, Asuni A, et al. An attenuated immune response is sufficient to enhance cognition in an Alzheimer's disease mouse model immunized with amyloid-beta derivatives. J Neurosci 2004;24:6277-82.

49. Chen G, Chen KS, Kobayashi D, et al. Active beta-amyloid immunization restores spatial learning in PDAPP mice displaying very low levels of beta-amyloid. J Neurosci 2007;27:2654-62.

50. Webster SD, Galvan MD, Ferran E et al. Antibody-mediated phagocytosis of the amyloid beta-peptide in microglia is differentially modulated by Clq. J Immunol 2001;166:7496-503.

51. Lemere CA, Spooner ET, LaFrancois J, et al. Evidence for peripheral clearance of cerebral Abeta protein following chronic, active Abeta immunization in PSAPP mice. Neurobiol Dis 2003;14:10-8.

52. Morgan D. Mechanisms of A beta plaque clearance following passive A beta immunization. Neurodegener Dis 2005;2:261-6.

53. Kim HD, Jin JJ, Maxwell JA, Fukuchi K. Enhancing Th2 immune responses against amyloid protein by a DNA primeadenovirus boost regimen for Alzheimer's disease. Immunol Lett 2007;112:30-8.

54. Qu B, Rosenberg RN, Li L, et al. Gene vaccination to bias the immune response to amyloid-beta peptide as therapy for Alzheimer disease. Arch Neurol 2004;61: 1859-64.

55. Chackerian B, Rangel M, Hunter Z, Peabody DS. Virus and virus-like particlebased immunogens for Alzheimer's disease induce antibody responses against amyloid-beta without concomitant $\mathrm{T}$ cell responses. Vaccine 2006;24: 6321-31.

56. Ghochikyan A, Petrushina I, Lees A, et al. Abeta-immunotherapy for Alzheimer's disease using mannan-amyloid-Beta peptide immunoconjugates. DNA Cell Biol 2006;25:571-80.

57. Ghochikyan A, Mkrtichyan M, Petrushina I, et al. Prototype Alzheimer's disease epitope vaccine induced strong Th2-type antiAbeta antibody response with Alum to Quil A adjuvant switch. Vaccine 2006;24:227582.

58. DaSilva K, Brown ME, Westaway D, McLaurin J. Immunization with amyloidbeta using GM-CSF and IL-4 reduces amyloid burden and alters plaque morphology. Neurobiol Dis 2006 23:433-44.

59. Maier M, Seabrook TJ, Lemere CA. Modulation of the humoral and cellular immune response in Abeta immunotherapy by the adjuvants monophosphoryl lipid A (MPL), cholera toxin B subunit (CTB) and E. coli enterotoxin LT(R192G). Vaccine 2005;23:5149-59.

60. Nikolic WV, Bai Y, Obregon D, et al. Transcutaneous beta-amyloid immunization reduces cerebral beta-amyloid deposits without $\mathrm{T}$ cell infiltration and microhemorrhage. Proc Natl Acad Sci USA, 2007;104:2507-12.

61. Goni F, Sigurdsson E.M. New directions towards safer and effective vaccines for Alzheimer's disease. Curr Opin Mol Ther 2005;7:7-23.

62. Schenk D, Hagen M, and Seubert P. Current progress in beta-amyloid immunotherapy. Curr Opin Immunol 2004; 16:599-606.

63. Karkos J. [Immunotherapy of Alzheimer's disease. Results of experimental investigations and treatment of perspectives]. Fortschr Neurol Psychiatr 2004; 72:204-19.

64. Ghidoni R, Benussi L, Glionna M, et al. Decreased plasma levels of soluble receptor for advanced glycation end products in mild cognitive impairment. J Neural Transm 2008;115:1047-50.

65. Maczurek A, Shanmugam K, Munch G. Inflammation and the redox-sensitive AGE-RAGE pathway as a therapeutic target in Alzheimer's disease. Ann N Y Acad Sci 2008;1126:147-51.

66. Stig B, Hajdu N. [Endproducts and receptors of advanced glycation and lipoxidation (AGE, ALE, RAGE) and chronic diseases from the perspective of food and nutrition]. Orv Hetil 2008;149:771-8.

67. Takeuchi M, Yamagishi S. Possible involvement of advanced glycation endproducts (AGEs) in the pathogenesis of Alzheimer's disease. Curr Pharm Des 2008;14:973-8.

68. Bayer AJ, Bullock R, Jones RW, et al. Evaluation of the safety and immunogenicity of synthetic Abeta42 (AN1792) in patients with AD. Neurology 2005 64:4101.

69. Pride M, Seubert P, Grundman M, et al. 
Progress in the active immunotherapeutic approach to Alzheimer's disease: clinical investigations into AN1792-associated meningoencephalitis. Neurodegener Dis 2008;5:194-6.

70. Nicoll JA, Wilkinson D, Holmes C, et al. Neuropathology of human Alzheimer disease after immunization with amyloidbeta peptide: a case report. Nat Med 2003; 9:448-52.

71. Orgogozo JM, Gilman S, Dartigues JF, et al. Subacute meningoencephalitis in a subset of patients with $\mathrm{AD}$ after Abeta42 immunization. Neurology 2003 61:46-54.

72. Gilman S, Koller M, Black RS, et al. Clinical effects of Abeta immunization (AN1792) in patients with $\mathrm{AD}$ in an interrupted trial. Neurology 2005;64:1553-62.

73. Hock C, Konietzko U, Streffer JR, et al. Antibodies against beta-amyloid slow cognitive decline in Alzheimer's disease. Neuron 2003;38:547-54.

74. Hock C, Konietzko U, Papassotiropoulos A, et al. Generation of antibodies specific for beta-amyloid by vaccination of patients with Alzheimer disease. Nat Med 2002 8:1270-5.

75. Hock C, Nitsch RM. Clinical observations with AN-1792 using TAPIR analyses. Neurodegener Dis 2005;2:273-6.

76. Kokjohn TA, Roher AE. Antibody responses, amyloid-beta peptide remnants and clinical effects of AN-1792 immunization in patients with $\mathrm{AD}$ in an interrupted trial. CNS Neurol Disord Drug Targets 2009;8:88-97.

77. Harrison J, Minassian SL, Jenkins L, et al. A neuropsychological test battery for use in Alzheimer disease clinical trials. Arch Neurol 2007;64:1323-9.

78. Masliah E, Hansen L, Adame A, et al. Abeta vaccination effects on plaque pathology in the absence of encephalitis in Alzheimer disease. Neurology, 2005. 64(1): p. 129-31.

79. Bombois S, Maurage CA, Gompel M, et al. Absence of beta-amyloid deposits after immunization in Alzheimer disease with Lewy body dementia. Arch Neurol 2007;64:583-7.

80. Patton RL, Kalback WM, Esh CL, et al. Amyloid-beta peptide remnants in AN1792-immunized Alzheimer's disease patients: a biochemical analysis. Am J Pathol 2006 169;1048-63.

81. Petrushina I, Ghochikyan A, Mktrichyan $\mathrm{M}$, et al. Alzheimer's disease peptide epitope vaccine reduces insoluble but not soluble/oligomeric Abeta species in amyloid precursor protein transgenic mice. J Neurosci 2007;27:12721-31.

82. Dodart JC, Bales KR, Gannon KS, et al. Immunization reverses memory deficits without reducing brain Abeta burden in Alzheimer's disease model. Nat Neurosci 2002;5:452-7.

83. Dickey CA, Morgan DG, Kudchodkar S, et al. Duration and specificity of humoral immune responses in mice vaccinated with the Alzheimer's disease-associated beta-amyloid 1-42 peptide. DNA Cell Biol 2001;20:723-9.

84. Munch G, Robinson SR. Potential neurotoxic inflammatory responses to Abeta vaccination in humans. J Neural Transm 2002;109:1081-7.

85. Pfeifer M, Boncristiano S, Bondolfi L, et al. Cerebral hemorrhage after passive antiAbeta immunotherapy. Science 2002;298: 1379.

86. Racke MM, Boone LI, Hepburn DL, et al. Exacerbation of cerebral amyloid angiopathy-associated microhemorrhage in amyloid precursor protein transgenic mice by immunotherapy is dependent on antibody recognition of deposited forms of amyloid beta. J Neurosci 2005;25:629-36.

87. Salloway S, Sperling R, Gilman S, et al. A phase 2 multiple ascending dose trial of bapineuzumab in mild to moderate Alzheimer disease. Neurology 2009;73: 2061-70.

88. Nikolic WV, Hou $\mathrm{H}$, Town $\mathrm{T}$, et al. Peripherally administered human umbilical cord blood cells reduce parenchymal and vascular beta-amyloid deposits in Alzheimer mice. Stem Cells Dev 2008;17: 423-39.

89. Obregon D, Hou H, Bai Y, et al. CD40L disruption enhances Abeta vaccine-mediated reduction of cerebral amyloidosis while minimizing cerebral amyloid angiopathy and inflammation. Neurobiol Dis 2008;29: 336-53.

90. Giunta S. Is inflammaging an auto[in - nate]immunity subclinical syndrome? Immun Ageing 2006;3:12.

91. Franceschi C, Capri M, Monti D, et al. Inflammaging and anti-inflammaging: a systemic perspective on aging and longevity emerged from studies in humans. Mech Ageing Dev 2007;128:92-105.

92. Grubeck-Loebenstein B, Blasko I, Marx FK, Trieb I. Immunization with beta-amyloid: could T-cell activation have a harmful effect? Trends Neurosci 2000;23:114.

93. Halliday G, Robinson SR, Shepherd C, Kril J. Alzheimer's disease and inflammation: a review of cellular and therapeutic mechanisms. Clin Exp Pharmacol Physiol, 2000;27:1-8

94. Retz W, Gsell W, Münch G, et al. Free radicals in Alzheimer's disease. J Neural Transm Suppl, 1998;54:221-36.

95. Almkvist 0 , Basun $\mathrm{H}$, Wagner SL, et al. Cerebrospinal fluid levels of alpha-secretase-cleaved soluble amyloid precursor protein mirror cognition in a Swedish family with Alzheimer disease and a gene mutation. Arch Neurol, 1997;54:641-4.

96. Gammon G, Sercarz E. How some T cells escape tolerance induction. Nature, 1989;342:183-5.

97. Peterson DA, DiPaolo RJ, Kanagawa 0, Unanue ER. Cutting edge: negative selection of immature thymocytes by a few peptide-MHC complexes: differential sensitivity of immature and mature $\mathrm{T}$ cells. $\mathrm{J}$ Immunol 1999;162:3117-20.

98. Janeway CA Jr. T-cell development: a role for self-peptides in positive selection. Curr Biol 1999;9:R342-5.

99. Wekerle H. T-cell autoimmunity in the central nervous system. Intervirology, 1993; 35:95-100.

100.Becher B, Prat A, Antel JP. Brain-immune connection: immuno-regulatory properties of CNS-resident cells. Glia 2000;29:293304.

101.Hickey WF. Basic principles of immunological surveillance of the normal central nervous system. Glia 2001;36:118-24.

102.Wyss-Coray T, Lin C, Yan F, et al. TGF-beta1 promotes microglial amyloid-beta clearance and reduces plaque burden in transgenic mice. Nat Med 2001;7:612-8. 